\title{
Salivary Cortisol Levels and Burning Symptoms in Patients with Burning Mouth Syndrome before and after Low Level Laser Therapy: a Double Blind Controlled Randomized Clinical Trial
}

\section{Razina kortizola i simptomi žarenja kod bolesnika sa sindromom pekućih usta prije i nakon liječenja niskoenergijskim laserom: dvostruko slijepa, kontrolirana i randomizirana klinička studija}

\footnotetext{
${ }^{1}$ Department of Oral Medicine, University Hospital Center Zagreb, Gundulićeva 5, 10000 Zagreb, Croatia Klinički zavod za bolesti usta Kliničkoga bolničkog centra Zagreb, Gundulićeva 5, 10000 Zagreb, Hrvatska

2 Department of Oral Medicine, School of Dental Medicine, University of Zagreb, Gundulićeva 5, 10000 Zagreb, Croatia Zavod za oralnu medicinu Stomatološkog fakulteta Sveučilišta u Zagrebu, Gundulićeva 5, 10000 Zagreb, Hrvatska

${ }^{3}$ Department of Oncology and Nuclear Medicine, University Clinical Hospital Sisters of Mercy, Vinogradska cesta 29, 10000 Zagreb, Croatia Zavod za onkologiju i nuklearnu medicinu Kliničkoga bolničkog centra Sestre milosrdnice, Vinogradska cesta 29, 10000 Zagreb, Hrvatska

${ }_{4}^{4}$ Department of Oral Medicine, School of Dental Medicine University of Zagreb and University Clinical Hospital Zagreb, Croatia Zavod za oralnu medicinu i Klinički zavod za bolesti usta Stomatološkog fakulteta Sveučilišta u Zagrebu, Croatia

${ }^{5}$ Department of Restorative Dentistry, School of Dental Medicine, University of Zagreb and University Hospital Zagreb, Croatia Zavod za endodonciju i restaurativnu stomatologiju Stomatološkog fakulteta Sveučilišta u Zagrebu, Hrvatska
}

\section{Abstract}

Objectives: Burning mouth syndrome (BMS) is a disorder which is described as burning sensation of the oral mucosa without pathological changes. Most of the patients have some underlying stressful conditions. Stress induces an increase in secretion of different endocrine glands resulting in higher levels of glucocorticoids. One of the options for treatment of BMS includes low level laser therapy (LLLT). The aim of this research was to determine salivary cortisol levels and intensity of burning symptoms in BMS patients before and after LLLT. Material and Methods: Twenty-three participants were allocated by randomization in two groups: 12 patients in the study group and 11 patients in the placebo group. Cortisol levels in all patients were analyzed from the sample of saliva collected without stimulation. In both groups, the LLLT was performed once a day for ten consecutive days (excluding weekend) with Ga-Al-As light-emitting diode type of laser, with a wavelength of $685 \mathrm{~nm}$. In the control group, LLLT was done with inactive laser probe which was only emitting audio signal. The intensity of burning symptoms was measured by a visual analogue scale (VAS). The VAS and unstimulated saliva were measured at baseline and on the last day of the LLLT. A quantitative analysis of saliva was performed using competitive commercial ELISA-kit. Results: VAS scores and salivary cortisol levels were significantly lower in both groups after LLLT. Conclusions: LLLT can be useful in patients with BMS for reducing burning symptoms and salivary cortisol level. Future studies on a larger number of patients should clarify whether the positive results are an outcome of laser effectiveness or of placebo effect.
Received: August 26, 2019

Accepted: February 3, 2020

Address for correspondence Božana Lončar Brzak University of Zagreb School of Dental Medicine Department of Oral Medicine Gundulićeva 5, 10000 Zagreb, Croatia Phone: 0038514802124 Fax: 0038514830819 loncar@sfzg.hr

Key words

Burning Mouth Syndrome; Saliva; Hydrocortisone; Low-Level Light Therapy

\section{Introduction}

Burning mouth syndrome (BMS) is a disorder which is described as burning sensation of oral mucosa without pathological changes (1). The etiology of BMS is unclear, although disorders of the central (2) or peripheral nervous system are possible causes. The most frequently affected sites are the anterior two thirds of the tongue although the BMS can affect any other intraoral site (3). Peri-menopausal and post - me-
Uvod

Sindrom pekućih usta (SPU) poremećaj je obilježen simptomima žarenja sluznice usta, bez vidljivih patoloških promjena (1). Etiologija mu je nejasna, iako se kao mogući uzroci spominju poremećaji središnjeg (2) ili perifernog živčanog sustava. Najčešće zahvaćena mjesta su prednje dvije trećine jezika, iako se može pojaviti na bio kojem intraoralnom mjestu (3). Najčešće obolijevaju žene u peri i postme- 
nopausal women are the most affected patients. It is hard to estimate the real epidemiology of BMS because of non-universal diagnostic criteria and, also, because of a low awareness about BMS among dentists and general health practitioners. Some studies from the literature have shown some nonspecific health problems in BMS patients, such as irritable bowel syndrome, headaches, temporomandibular joint pain, dermatological, musculoskeletal and psychiatric disorders (4) as well as higher level of catastrophizing is some patients (5). The majority of the patients have some underlying stressful conditions. Also, the burning symptoms itself could increase the level of stress in patients with BMS.

Stress induces an increase in secretion of different endocrine glands resulting in higher levels of glucocorticoids (6). Cortisol is a glucocorticoid which is secreted from the adrenal cortex. It is involved in the metabolism of carbohydrates, proteins and fats. In addition, it has a role in water metabolism, affects the sensitivity of the nervous system and affects the human stress response (3). Results from the literature point out that cortisol levels in saliva are increased in BMS patients as indicator of stress conditions $(3,7)$. However, Nosratzehi et al. (8) and de Souza et al. (9) have shown that differences between salivary cortisol levels among BMS patients and control were not significant.

The estimation of cortisol in saliva is a non-invasive procedure as opposed to blood collection which induces stress in some patients leading to an increase in cortisol levels (10). Due to an advance in analytical methods, the levels of cortisol and cortisone in saliva can be measured with high reliability. The reference interval is determined by the manufacturer of the specific kit.

A recent study (11) has shown that women with temporomandibular disorders and salivary cortisol above $10 \mathrm{ng} / \mathrm{ml}$ reported higher pain scores. This result points out the involvement of stress in other painful conditions in the orofacial region.

The treatment of BMS is difficult and represents a serious clinical problem. Various treatment possibilities have been suggested but with limited success. According to a recent systematic review, a certain intervention for patient with BMS has not been proposed (12).

Low level laser therapy (LLLT) as a treatment option includes the use of light to a biologic system in order to promote tissue regeneration, reduce inflammation and relieve pain (13). The results regarding LLLT in BMS patients are controversial and require further investigation.

The aim of this research was to determine the salivary cortisol levels and intensity of burning symptoms in BMS patients before and after LLLT. To our knowledge, this is the first study evaluating the effect of LLLT on salivary cortisol levels in BMS patients.

\section{Material and methods}

This was a double-blinded randomized clinical trial approved by the Ethics Committee of the School of Dental Medicine, University of Zagreb, Croatia. The written consent form was signed by each patient consistent with the Decla- nopauzi. Stvarnu epidemiologiju SPU-a teško je ustanoviti zbog manjka univerzalnih dijagnostičkih kriterija i svjesnosti o tom sindromu među doktorima dentalne i opće medicine. U studijama iz literature ističu se nespecifični problemi bolesnika sa SPU-om, kao što su sindrom iritabilnog crijeva, glavobolje, bol u čeljusnome zglobu, dermatološke, mišićnokoštane i psihijatrijske bolesti (4) te povišena razina katastrofičnosti kod pojedinih bolesnika (5). Većina bolesnika ima u podlozi određeno stresno stanje. Simptomi žarenja također mogu povisiti razinu stresa kod bolesnika sa SPU-om.

Stres potiče izlučivanje različitih endokrinih žlijezda, što također rezultira povišenom razinom glukokortikoida (6). Kortizol je glukokortikoidni hormon koji izlučuje kora nadbubrežne žlijezde. Uključen je u metabolizam ugljikohidrata, proteina i masti. Ima i ulogu u metabolizmu vode, utječe na osjetljivost živčanog sustava i na odgovor na stres (3). Rezultati prijašnjih istraživanja upućuju na povišenu razinu kortizola u slini bolesnika sa SPU-om kao indikatora stresnih situacija $(3,7)$. No Nosratzehi i suradnici (8) i de Souza i njegovi kolege (9) nisu zapazili značajnu razliku u razini kortizola u slini među bolesnicima sa SPU-om i onima iz kontrole.

Određivanje kortizola u slini neinvazivna je procedura, suprotno od vađenja krvi koje kod pojedinih bolesnika izaziva stres te tako povisuje razinu kortizola (10). Zbog napretka $\mathrm{u}$ analitičkim metodama razina kortizola i kortizona u slini može se mjeriti s velikom pouzdanošću. Referentni interval određuje proizvođač specifičnoga kita.

U nedavnoj studiji (11) ističe se da žene s temporomandibularnim poremećajima i razinom kortizola u slini $>10 \mathrm{ng} /$ $\mathrm{ml}$ imaju veći intenzitet boli. Taj rezultat upućuje na ulogu stresa u ostalim bolnim poremećajima u orofacijalnom području.

Liječenje SPU-a težak je i ozbiljan je klinički problem. Predložene su različite mogućnosti liječenja, ali s ograničenim uspjehom. Prema nedavnome sustavnom pregledu, određena intervencija za bolesnike sa SPU-om nije predložena (12).

Liječenje niskoenergijskim laserom uključuje upotrebu svjetla prema biološkom sustavu u svrhu poticanja regeneracije tkiva, smanjenja upale i olakšanja boli (13). Rezultati liječenja bolesnika sa SPU-om niskoenergijskim laserom oprečni su i zahtijevaju daljnja istraživanja.

Cilj ovog istraživanja bio je odrediti razinu kortizola u slini i jakost žarenja kod bolesnika sa SPU-om prije liječenja niskoenergijskim laserom i nakon njega. Prema našoj spoznaji, ovo je prva studija koja kod bolesnika sa SPU-om procjenjuje učinak liječenja niskoenergijskim laserom na razinu kortizola u slini.

\section{Materijali i metode}

Ovo je bila dvostruko slijepa, randomizirana klinička studija koju je odobrilo Etičko povjerenstvo Stomatološkog fakulteta Sveučilišta u Zagrebu. Svi bolesnici potpisali su informirani pristanak u skladu s Helsinškom deklaracijom. U 
ration of Helsinki. There were 12 patients in the study group and 11 patients in the control group. Sample size was calculated according to previously published data (14) by power analysis with significance level $\alpha=0.05$ and power $\beta=0.8$. Participants were randomly allocated into two groups by random number generator.

Inclusion criteria were patients with burning sensations for at least three months before the treatment and with normal appearance of the oral mucosa. Burning sensations were present on only one intraoral site - the tongue, lip or hard palate. The patients with BMS came to our Department for the first time and they had not had any previous treatments for BMS. Excluding criteria were patients with diabetes, serum iron and vitamin B deficiency, previous head and neck radiotherapy, patients with autoimmune diseases and those taking antidepressants, anxiolytics, anticonvulsants and hormonal therapy which could affect cortisol level.

Primary outcome measure was a patient's subjective complaint of burning sensation detected by a visual analogue scale (VAS) grading 0 to 10 , with level 10 representing the strongest level of symptoms.

The secondary outcome measure was the salivary cortisol level in unstimulated saliva. Saliva was collected between 9AM and 10AM by spitting into grading tubes which were immediately frozen. Teeth brushing and eating or drinking was not allowed for 60 minutes before saliva sampling.

VAS scale and unstimulated saliva were measured at baseline and last day of the LLLT.

On the assay day, saliva samples were defrosted and concentrations of cortisol were determined by manufacturer's instructions for Salimetrics commercial ELISA-kit (Salimetrics, LCC, State College, PA, USA). The range of manufacturer's reference values was from $0.007-0.115 \mu \mathrm{g} / \mathrm{dL}$.

In the study group, the LLLT was done daily for ten consecutive days (excluding weekend) (15) with Ga-Al-As lightemitting diode type of laser by a third person - nurse from our clinical Department in what way randomization was enabled. Laser wavelength was $685 \mathrm{~nm}$ and treatment was performed on three reported burning sites. LLLT parameters are shown in Table 1.

The treatment protocol was identical for the control group, but LLLT was done with inactive laser probe which was only emitting the audio signal. ispitnoj skupini bilo je dvanaestero, a u kontrolnoj jedanaestero bolesnika. Veličina uzorka izračunata je prema prije objavljenim podatcima (14) s pomoću analize snage $s$ razinom značajnosti $\alpha=0,05$ i snagom $\beta=0,8$. Ispitanici su raspodijeljeni u dvije skupine s pomoću generatora slučajnih brojeva.

Kriteriji za sudjelovanje bili sa simptomi žarenja barem tri mjeseca prije liječenja i uredan nalaz sluznice usta. Simptomi žarenja bili su na samo jednom intraoralnom mjestu na jeziku, usnici ili tvrdom nepcu. Bolesnici sa SPU-om došli su u naš zavod prvi put i prije toga nisu bili liječeni zbog tog sindroma. Kriteriji za nesudjelovanje bili su šećerna bolest, manjak serumskog željeza i vitamina B, obavljeno liječenje zračenjem glave i vrata, autoimune bolesti te uzimanje antidepresiva, antikonvulziva i hormona, što je moglo utjecati na razinu kortizola.

Primarna mjera ishoda bila je subjektivni osjećaj žarenja izmjeren vizualno analognom ljestvicom boli (VAS-om) gradiranom od 0 do 10 , s time da je 10 pokazatelj najjače boli.

Sekundarna mjera ishoda bila je razina kortizola u nestimuliranoj slini. Slina se skupljala između 9 i 10 sati pljuvanjem u graduiranu epruvetu, a uzorci su odmah zamrznuti. Sezdeset minuta prije toga bolesnici nisu prali zube, te nisu jeli, niti pili.

Razina simptoma na VAS ljestvici i nestimulirana slina mjereni su na početku liječenja i posljednjega dana tretmana niskoenergijskim laserom.

$\mathrm{Na}$ dan testa uzorci sline su odmrznuti te su koncentracije kortizola određene prema uputama proizvođača komercijalnog kita Salimetrics ELISA (Salimetrics, LCC, State College, PA, SAD). Raspon referentnih vrijednosti proizvođača bio je od 0,007 do $0,115 \mu \mathrm{g} / \mathrm{dL}$.

$\mathrm{U}$ ispitnoj skupini liječenje niskoenergijskim laserom obavljalo se deset dana (isključujući vikend) (15) s Ga-Al-As svjetlosno emitirajućom diodom lasera s pomoću treće osobe - medicinske sestre iz našeg zavoda te se na taj način omogućila randomizacija. Valna duljina lasera bila je $685 \mathrm{~nm}$, a liječenje je provedeno na trima mjestima. Parametri niskoenergijskog lasera nalaze se u tablici 1 .

Protokol liječenja bio je isti i u kontrolnoj skupini, ali je liječenje obavljeno inaktivnom laserskom sondom emitirajući samo zvučni signal.

\begin{tabular}{|c|c|c|c|}
\hline \multirow[t]{5}{*}{ Table 1.} & \multirow{5}{*}{$\begin{array}{l}\text { Relevant technical data for LLLT } \\
\text { (BTL2000 Medical Technologies, s.r.o., } \\
\text { Czech Republic) } \\
\text { Relevantni tehnički podatci za liječenje } \\
\text { niskoenergijskim laserom (BTL2000 } \\
\text { Medical Technologies, s.r.o., Češka) }\end{array}$} & Parameter (unit) • Parametar (jedinica) & Value $\bullet$ Vrijednost \\
\hline & & Wavelenght $(\mathrm{nm}) \cdot$ Valna duljina $(\mathrm{nm})$ & 685 \\
\hline & & Dose $(\mathrm{J} / \mathrm{cm} 2) \cdot \operatorname{Doza}(\mathrm{J} / \mathrm{cm} 2)$ & 2.00 \\
\hline & & Power $(\mathrm{mW}) \bullet$ Snaga $(\mathrm{mW})$ & 30 \\
\hline & & Power density $(\mathrm{W} / \mathrm{cm} 2) \cdot$ Gustoća snage $\left(\mathrm{W} / \mathrm{cm}^{2}\right)$ & 0.003 \\
\hline & & Number of treatments $\bullet$ Broj tretmana & 10 \\
\hline & & Single treatment duration $(\mathrm{sec}) \bullet$ Trajanje pojedinačnog tretmana (sek.) & 381 \\
\hline & & Treated surface area $(\mathrm{cm} 2) \bullet$ Tretirana površina $\left(\mathrm{cm}^{2}\right)$ & 3 \\
\hline & & Distance $(\mathrm{cm}) \bullet$ Udaljenost $(\mathrm{cm})$ & 0.5 \\
\hline & & Frequency $(\mathrm{Hz}) \bullet$ Frekvencija $(\mathrm{Hz})$ & 5.20 \\
\hline & & Cumulative dose $(\mathrm{J} / \mathrm{cm} 2) \bullet$ Kumulativna doza $\left(\mathrm{J} / \mathrm{cm}^{2}\right)$ & 60 \\
\hline
\end{tabular}




\section{Statistical analysis}

Statistical analysis was performed by MedCalc statistical software, version 18.10.2. (Ostend, Belgium). Differences between groups regarding age and sex were tested by the Mann-Whitney and Fischer-exact test respectively. The Wilcoxon signed-rank test for related samples was used to compare the differences between VAS scores and salivary cortisol level before and after LLLT. The level of significance was set at $0.05(\mathrm{p}<0.05)$.

\section{Results}

A total of 23 patients, 20 women and three men (one in the study group and two in the control group) participated in the study. Median age of the patients in the study group was $61(47-70)$ years and in the control group $62(50-69)$ years. Age and sex distribution did not differ between groups (Table 2). All participants have completed the study without any reported side effects of the therapy as evidenced by their subjective responses and control examination of the oral mucosa. The results have shown that VAS scores were significantly lower in both groups after LLLT (study group: median 5.5 (4-9) to median 4 (3-7); control group: median $5(0-8)$ to median 3 (1.5-6.5)) (Table 3).

Our results have shown that all patients had elevated salivary cortisol levels prior to the LLLT $(>0.115 \mu \mathrm{g} / \mathrm{dL})$. Decreased salivary cortisol levels were detected in both groups after LLLT (study group: median 0.337 (0.198-1.333) $\mu \mathrm{g} / \mathrm{dL}$ to median $0.305(0.122-0.831) \mu \mathrm{g} / \mathrm{dL}$; control group: median $0.313(0.137-0.85) \mu \mathrm{g} / \mathrm{dL}$ to median $0.222(0.122-0.498)$ $\mu \mathrm{g} / \mathrm{dL}$ (Table 3).

\section{Statistička analiza}

Statistička analiza obavljena je softverom MedCalc, verzija 18.10.2. (Ostende, Belgija). Razlike između skupina, kada je riječ o dobi i spolu, testirane su Mann-Whitneyjevim i Fisherovim egzaktnim testom. Za usporedbu VAS bodova i razine kortizola u slini prije liječenja niskoenergijksim laserom i nakon toga postupka korišten je Wilcoxov signed-rank test za zavisne uzorke. Razina značajnosti postavljena je na 0,05 $(\mathrm{p}<0,05)$.

\section{Rezultati}

U studiji je sudjelovalo ukupno dvadeset i troje bolesnika - dvadeset žena i trojica muškaraca (jedan u ispitnoj skupini i dvojica u kontrolnoj). Medijan godina u ispitnoj skupini bio je 61 (47 - 70), a u kontrolnoj $62(50$ - 69). Raspodjela prema dobi i spolu nije se razlikovala među skupinama (tablica 2.). Svi ispitanici završili su istraživanje bez prijavljenih nuspojava, što je evidentirano prema subjektivnom odgovoru i kontrolnom pregledu oralne sluznice. Rezultati su pokazali da su VAS bodovi bili značajno niži u obje skupine nakon liječenja niskoenergijskim laserom (ispitna skupina: medijan 5,5 (4 - 9) prema medijanu 4 (3 -7); kontrolna skupina: medijan $5(0-8)$ prema medijanu $3(1,5-6,5)$ (tablica 3.).

Naši rezultati pokazali su da su svi bolesnici imali povišene vrijednosti kortizola u slini prije liječenja niskoenergijjskim laserom $(>0,115 \mu \mathrm{g} / \mathrm{dL})$. Smanjene vrijednosti kortizola u slini detektirane su u obje skupine nakon liječenja niskoenergijskim laserom (ispitna skupina: medijan 0,337 (0,198 - 1,333) $\mu \mathrm{g} / \mathrm{dL}$ prema medijanu $0,305(0,122-0,831) \mu \mathrm{g} /$ $\mathrm{dL}$; kontrolna skupina: medijan $0,313(0,137-0,85) \mu \mathrm{g} / \mathrm{dL}$ prema medijanu 0,222 $(0,122-0,498) \mu \mathrm{g} / \mathrm{dL}$ (tablica 3.).

\begin{tabular}{|c|c|c|c|c|c|}
\hline \multirow{6}{*}{$\begin{array}{l}\text { Table } 2 \\
\text { Tablica } 2 .\end{array}$} & \multirow{6}{*}{$\begin{array}{l}\text { Caracteristics of the study and control } \\
\text { group } \\
\text { Karakteristike ispitne i kontrolne } \\
\text { skupine }\end{array}$} & & $\begin{array}{l}\text { Study group • } \\
\text { Ispitna skupina }\end{array}$ & $\begin{array}{l}\text { Control group } \\
\text { Kontrolna skupina }\end{array}$ & $\mathbf{P}$ \\
\hline & & Male $(\mathrm{N}) \bullet \operatorname{Muškarci}(\mathrm{N})$ & 1 & 2 & \multirow{3}{*}{$>0.05^{*}$} \\
\hline & & Female $(\mathrm{N}) \bullet$ Žene $(\mathrm{N})$ & 11 & 9 & \\
\hline & & Total $(\mathrm{N}) \bullet \operatorname{Ukupno}(\mathrm{N})$ & 12 & 11 & \\
\hline & & $\begin{array}{l}\text { Age } \bullet \text { Godine } \\
\text { Median (range) } \bullet \text { Medijan (raspon) }\end{array}$ & $61(47-70)$ & $62(50-69)$ & $>0.05^{* *}$ \\
\hline & & \multicolumn{4}{|c|}{$\begin{array}{l}{ }^{*} \text { Fisher-exact test } \bullet \text { Fisherov egzaktni test } \\
{ }^{* *} \text { Mann-Whitney test } \bullet \text { Mann-Whitneyjev test }\end{array}$} \\
\hline
\end{tabular}

\begin{tabular}{|c|c|c|c|c|c|c|}
\hline & $\begin{array}{c}\text { VAS scores before } \\
\text { LLLT } \bullet \\
\text { VAS bodovi prije } \\
\text { liječenja } \\
(\text { median }(\text { range })) \bullet \\
(\text { medijan (raspon) })\end{array}$ & $\begin{array}{l}\text { VAS scores after LLLT • } \\
\text { VAS bodovi nakon } \\
\text { liječenja } \\
(\text { median (range) }) \bullet \\
(\text { medijan (raspon) })\end{array}$ & $\mathbf{P}^{*}$ & $\begin{array}{c}\text { Salivary cortisol level } \\
\text { before LLLT } \bullet \text { Razina } \\
\text { kortizola u slini prije } \\
\text { liječenja } \\
(\text { median (range) } \mu \mathrm{g} / \mathrm{dL}) \bullet \\
(\text { medijan }(\text { raspon) } \mu \mathrm{g} / \mathrm{dL})\end{array}$ & $\begin{array}{c}\text { Salivary cortisol level } \\
\text { after LLLT } \bullet \text { Razina } \\
\text { kortizola u slini nakon } \\
\text { liječenja } \\
(\text { median }(\text { range) } \mu \mathrm{g} / \mathrm{dL}) \bullet \\
(\text { medijan (raspon) } \mu \mathrm{g} / \mathrm{dL})\end{array}$ & $\mathbf{P}^{*}$ \\
\hline $\begin{array}{l}\text { Laser probe turned on } \\
\text { Uključena laserska sonda }\end{array}$ & $5.5(4-9)$ & $4(3-7)$ & $<0.05$ & $0.377(0.198-1.333)$ & $0.305(0.122-0.831)$ & $<0.05$ \\
\hline $\begin{array}{l}\text { Laser probe turned off } \\
\text { Isključena laserska sonda }\end{array}$ & $5(0-8)$ & $3(1.5-6.5)$ & $<0.05$ & $0.313(0.137-0.85)$ & $0.222(0.122-0.498)$ & $<0.05$ \\
\hline
\end{tabular}




\section{Discussion}

The results of scientific studies published so far regarding the treatment of BMS patients with LLLT are not consistent. Additionally, previous studies have shown controversial results regarding the salivary cortisol levels in BMS patients. Amenábar et al. (3) and Kim et al. (7) have shown elevated cortisol levels in BMS patients, which is in disagreement with Nosratzehi et al. (8) and de Souza et al. (9).

In our study, we have reported decreased salivary cortisol levels in BMS patients after the LLLT when the laser diode was switched on and when the laser diode was switched off. Bearing in mind the fact that the cortisol level increases in stress situations (6), we may assume that patients were less stressed after the therapy. The patients also had a smaller number of burning symptoms after the therapy, which was confirmed by decreased VAS scores that were significantly lower after the LLLT in both groups. Similar results were obtained by Sikora et al. (15) who also reported decreased VAS scores in BMS patients regardless of the laser probe being on or off.

A recent study of Spanemberg et al. (14) has shown that the effect of LLLT was satisfactory in a small number of BMS patients and that LLLT could be alternative to treatment with psychoactive drugs. Their study included 12 patients in the study group and 9 patients in the control group. This study differs from ours in the treatment protocol -2 weekly sessions for 4 weeks (14) contrary to 5 weekly sessions for 2 weeks (ours) and laser wavelength - infrared (14) contrary to red (ours). A group of authors in 2015 (16) have reported a reduction of burning symptoms in BMS patients treated with three different laser treatment protocols including infrared and red diode and different weekly application. These data point out that different modality of LLLT could be effective in treatment of patients with BMS but also a need for defining a standard protocol for low level laser therapy in BMS patients.

Valenzuela and Lopez-Jornet (17) reported that LLLT reduces symptoms slightly in BMS patients which they obtained by use of OHIP-14, VAS and Hospital anxiety and depression scale. Their results have shown that OHIP-14 and VAS scores were significantly lower after two weeks. However, no significant reduction was found from 2 to 4 weeks therapy.

Al-Maweri et al. (18) made a systemic meta-analysis of the published literature on BMS and LLLT and included results of five randomized clinical trials $(16,19-22)$, three uncontrolled clinical trials (23-25) and two case series (26, 27). Sugaya et al. (19) have found that LLLT has the same effect as placebo in BMS patients. Pezelj-Ribaric et al. (22) did not find any significant reductions of VAS scores after LLLT. Although the abovementioned studies have shown negative results, AlMaweri et al. (18) concluded that LLLT could be effective for reducing pain in BMS patients. They pointed out that well designed double-blinded randomized clinical trials are necessary to evaluate the role of LLLT in patients with BMS.

The results of previous studies have shown an association between pain intensity, salivary cortisol levels and psycho-

\section{Rasprava}

Rezultati dosad objavljenih studija o liječenju bolesnika sa SPU-om niskoenergijskim laserom nisu konzistentni. Nadalje, u dosadašnjim studijama postignuti su oprečni rezultati kad je riječ o razini kortizola u slini bolesnika sa SPU-om. Amenábar i suradnici (3) te Kim i suradnici (7) upozorili su povišene razine kortizola u slini bolesnika sa SPU-om, što je suprotno rezultatima Nosratzehija i suradnika (8) te de Souze i suradnika (9).

U našoj studiji dobili smo snižene razine kortizola u slini bolesnika sa SPU-om nakon liječenja niskoenergijskim laserom, bilo da je laserska sonda bila uključena ili isključena. Znajući da se razina kortizola povisuje u stresnim situacijama (6), možemo pretpostaviti da su bolesnici nakon liječenja bili u manjem stresu. Također su imali slabije simptome žarenja, što je potvrđeno značajnim smanjenjem VAS bodova u obje skupine. Slične rezultate dobili su Sikora i suradnici (25) koji su također istaknuli smanjenje VAS bodova kod bolesnika sa SPU-om pri uključenoj i isključenoj laserskoj sondi.

U nedavnoj studiji Spanemnberga i suradnika (14) ističe se da je učinak liječenja niskoenergijskim laserom bio zadovoljavajući kod malog broja bolesnika sa SPU-om te da takav tretman može biti alternativa liječenju psihoaktivnim drogama. U njihovoj studiji sudjelovalo je dvanaestero bolesnika u ispitnoj skupini i devetero u kontrolnoj. Ta se studija od naše razlikuje prema protokolu liječenja - dva puta na tjedan tijekom četiri tjedna (14) prema pet puta na tjedan tijekom dva tjedna (naša studija). Grupa autora pokazala je u 2015. 16 smanjenja simptoma žarenja kod bolesnika sa SPU-om liječenih niskoenergijskim laserom prema različitim protokolima, uključujući infracrvenu i crvenu sondu te različitu tjednu primjenu. Ti podatci upućuju na to da različiti modaliteti liječenja niskoenergijskim laserom mogu biti učinkoviti u liječenju bolesnika sa SPU-om, ali i da je potrebno definirati standardni protokol za liječenje bolesnika sa SPU-om niskoenergijskim laserom.

Valenzuela i Lopez-Jornet (17) izvijestili su da liječenje niskoenergijskim laserom malo smanjuje simptome kod bolesnika sa SPU-om koji su zabilježeni s pomoću OHIP-a 14, VAS-a i bolničke ljestvice za mjerenje anksioznosti i depresije. No od drugoga do četvrtog tjedna liječenja nije uočeno značajno smanjenje simptoma.

Al-Maweri i suradnici (18) obavili su sustavnu metaanalizu literature o SPU-u i liječenju niskoenergijskim laserom te uključili rezultate pet randomiziranih kliničkih studija (16, $19-22)$, triju nekontroliranih kliničkih studija $(23-25)$ i dviju serija slučajeva $(26,27)$. Sugaya i suradnici (19) istaknuli su da liječenje niskoenergijskim laserom u slučaju bolesnika sa SPU-om ima isti učinak kao placebo. Pezelj-Ribarić i suradnici (22) nisu pronašli značajno smanjenje VAS bodova nakon liječenja niskoenergijskim laserom. Iako su u spomenutim studijama postignuti negativni rezultati, Al-Maweri i suradnici (18) zaključili su da liječenje niskoenergijskim laserom može učinkovito smanjiti bol kod bolesnika sa SPU-om. Istaknuli su da su potrebne dobro dizajnirane dvostruko slijepe randomizirane kliničke studije za procjenu liječenja niskoenergijskim laserom bolesnika sa SPU-om. 
logical stress $(28,29)$. Also, the patients with chronic pain show greater improvement when they get treatment, whether or not it is a placebo, than without any therapy at all (30). Every possible treatment option is associated with beneficial cognitive effects such as stress reduction $(31,32)$. Although Vukoja et al. (33) suggest that positive effect of LLLT is probably the result of a placebo, previous data (30-32) justifies the use of LLLT despite possible placebo effects.

The advantages of our study are that, to our knowledge, this is the first study measuring salivary cortisol levels in patients with BMS before and after LLLT. The limitations of the study refer to cortisol measurement that may be affected by wake up-time and it cannot be influenced by the researcher (34).

\section{Conclusion}

Despite the limitations of the study, our results have shown that LLLT can be useful for reducing burning symptoms and the salivary cortisol level, thus reducing stress. However, further research on a larger number of BMS patients is needed to clarify whether the positive results are attributed to LLLT effectiveness or to placebo effect.

\section{Conflict of Interest}

None declared.
Rezultati dosadašnjih studija pokazali su povezanost između intenziteta boli, razine kortizola u slini i psihološkog stresa $(28,29)$. Uz to, bolesnici s kroničnom boli ističu značajno poboljšanje nakon što dobiju terapiju, radi li se o placebo učinku ili ne, u odnosu prema izostanku liječenja (30). Svako moguće liječenje povezano je s pozitivnim kognitivnim posljedicama kao što je smanjenje stresa $(31,32)$. Iako su Vukoja i suradnici (33) sugerirali da je pozitivan učinak liječenja niskoenergijskim laserom vjerojatno rezultat placeba, dosadašnji podatci $(30-32)$ opravdavaju upotrebu toga uređaja unatoč mogućem placebo efektu.

Prednost naše studije jest da je, prema našem znanju, to prva studija koja mjeri razinu kortizola u slini bolesnika sa SPU-om prije liječenja niskoenergijskim laserom i nakon toga postupka. Ograničenje studije odnosi se na mjerenje kortizola na koje može utjecati vrijeme buđenja, a na koje istraživač ne može utjecati (34).

\section{Zaključak}

Unatoč ograničenjima studije, naši su rezultati pokazali da liječenje niskoenergijskim laserom može biti korisno za smanjenje simptoma pečenja i razinu kortizola u slini i tako smanjiti stres. No potrebne su studije na većem broju bolesnika sa SPU-om u kojima bi se trebalo razjasniti jesu li pozitivni rezultati ishod učinkovitosti lasera ili placebo učinka.

\section{Sukob interesa}

Autori nisu bili u sukobu interesa.

\section{Sažetak}

Uvod: Sindrom pekućih usta (SPU) poremećaj je obilježen simptomima žarenja sluznice usta bez vidljivih patoloških promjena. Većina bolesnika ima u podlozi određeno stresno stanje. Stres potiče izlučivanje različitih endokrinih žlijezda, što rezultira i povišenom razinom glukokortikoidnih hormona. Jedna od opcija u liječenju SPU-a uključuje i niskoenergijski laser. Cilj: Svrha ovog istraživanja bila je utvrditi razinu kortizola u slini i jakost simptoma žarenja kod bolesnika sa SPU-om prije liječenja niskoenergijskim laserom i poslije tog postupka. Materijali i metode: $U$ dvije skupine slučajnim je odabirom podijeljeno dvadeset $\mathrm{i}$ troje ispitanika - dvanaestero je bilo $\mathrm{u}$ ispitnoj $\mathrm{i}$ jedanaestero u placebo skupini. Svakomu od njih određena je razina kortizola u nestimuliranoj slini. U obje se skupine liječenje niskoenergijskim laserom provodilo jedanput na dan tijekom deset dana (isključujući vikend) diodnim tipom lasera Ga-Al-As valne duljine $685 \mathrm{~nm}$. U kontrolnoj skupini liječenje je obavljeno inaktivnom sondom lasera odašiljajući samo zvučni signal. Intenzitet simptoma žarenja mjeren je s pomoću vizualno analogne ljestvice (VAS-a). VAS i nestimulirana slina mjereni su na početku istraživanja i posljednjeg dana liječenja niskoenergijskim laserom. Analiza sline obavljena je komercijalnim kitom ELISA.Rezultati: U obje skupine su VAS bodovi i razina kortizola u slini bili značajno niži nakon liječenja niskoenergijskim laserom. Zaključak: Niskoenergijski laser može bolesnicima sa SPU-om smanjiti jakost žarenja i razinu kortizola u slini. Buduće studije na većem broju ispitanika trebale bi razjasniti je li pozitivan učinak rezultat učinkovitosti lasera ili je placebo efekt.
Zaprimljen: 26. kolovoza 2019. Prihvaćen: 3. veljače 2020.

Adresa za dopisivanje Božana Lončar Brzak Sveučilište u Zagrebu Stomatološki fakultet Zavod za oralnu medicinu Gundulićeva 5, 10000 Zagreb, Hrvatska tel: 0038514802124

faks: 0038514830819 loncar@sfzg.hr

Ključne riječi

sindrom pekućih usta; slina; kortizol; liječenje niskoenergijskim laserom

\section{References}

1. Grushka M, Epstein J.B, Gorsky M. Burning mouth syndrome. Am Fam Physician. 2002 Feb 15;65(4):615-20.

2. Zavoreo I, Vučićević V, Boras, Zadravec D, Bašić V, Kes. Ciliga D, Gabrić D. The Significance of Brain Transcranial Sonography in Burning Mouth Syndrome: a Pilot Study. Acta Stomatol Croat. 2017 Mar;51(1):48-59.

3. Amenábar JM, Pawlowski J, Hilgert JB, Hugo FN, Bandeira D, Lhüller F, et al. Anxiety and salivary cortisol levels in patients with burning mouth syndrome: case-control study. Oral Surg Oral Med Oral Pathol Oral Radiol Endod. 2008 Apr;105(4):460-5.

4. Klasser GD, Fischer DJ, Epstein JB. Burning mouth syndrome. Recognition, understanding and management. Oral Maxillofac Surg Clin North Am. 2008 May;20(2):255-71, vii.
5. Rogulj AA, Richter I, Brailo V, Krstevski I, Boras VV. Catastrophizing in patients with burning mouth syndrome. Acta Stomatol Croat. 2014 Jun; 48(2):109-15.

6. Ranabir S, Reetu K. Stress and Hormones. Indian J Endocrinol Metab. 2011 Jan;15(1):18-22.

7. Kim HI, Kim YY, Chang JY, Ko JY, Kho HS. Salivary cortisol, $17 \beta$-estradiol, progesterone, dehydroepiandrosterone, and $\alpha$-amylase in patients with burning mouth syndrome. Oral Dis. 2012 Sep;18(6):613-20.

8. Nosratzehi T, Salimi S. Parvaee A. Comparison of Salivary Cortisol and $\alpha$-amylase Levels and Psychological Profile sin Patients with Burning Mouth Syndrome. Spec Care Dent. 2017;37(3):120-5.

9. de Souza FT, Kummer A, Silva ML, Amaral TM, Abdo EN, Abreu $\mathrm{MH}$, et al. The association of openness personality trait with 
stress-related salivary biomarkers in burning mouth syndrome. Neuroimmunomodulation. 2015;22(4):250-5.

10. Blair J, Adaway J, Keevil B, Ross R. Salivary cortisol and cortisone in the clinical setting. Curr Opin Endocrinol Diabetes Obes. 2017 Jun;24(3):161-168.

11. Magri LV, Carvalho VA, Rodrigues FCC, Bataglion C, Leite-Panissi CRA. Non-specific effects and clusters of women with painful TMD responders and non-responders to LLLT: double blind randomized clinical trial. Lasers Med Sci. 2018 Feb;33(2):385-392.

12. McMillan R, Forssell H, Buchanan JAG, Glenny AM, Weldon JC, Zakrzewska JM. Interventions for treating burning mouth syndrome. Cochrane Database Syst Rev. 2016 Nov 18;11:CD002779.

13. Farivar S, Malekshahabi T, Shiari R. Biological Effects of Low Level Laser Therapy. J Lasers Med Sci. 2014 Spring;5(2):58-62.

14. Spanemberg IC, Segura-Egea JJ, Rodríguez-de Rivera-Campillo E, Jané-Salas E, Salum FG, López-López J. Low-level laser therapy in patients with Burning Mouth Syndrome: A double-blind, randomized, controlled clinical trial. J Clin Exp Dent. 2019 Feb 1;11(2):e162-e169.

15. Sikora M, Včev A, Siber S, Vučićević Boras V, Rotim Ž, Matijević $M$. The Efficacy of Low-Level Laser Therapy in Burning Mouth Syndrome - A Pilot Study. Acta Clin Croat. 2018;57(2):312-5.

16. Spanemberg JC, López JL, de Figueiredo MA, Cherubini K, Salum FG. Efficacy of low-level laser therapy for the treatment of burning mouth syndrome: a randomized, controlled trial. J Biomed Opt. 2015 Sep;20(9):098001.

17. Valenzuela S, Lopez-Jornet P. Effects of low-level laser therapy on burning mouth syndrome. J Oral Rehabil. 2017 Feb;44(2):125132.

18. Al-Maweri SA, Javed F, Kalakonda B, AlAizari NA, Al-Soneidar W, Al-Akwa A. Efficacy of low level laser therapy in the treatment of burning mouth syndrome: A systematic review. Photodiagnosis Photodyn Ther. 2017 Mar;17:188-193.

19. Sugaya NN, Silva EF, Kato IT, Prates R, Gallo CB, Pellegrini VD. Low Intensity laser therapy in patients with burning mouth syndrome: a randomized, placebo-controlled study. Braz Oral Res. 2016 Oct 10;30(1):e108.

20. Arbabi-Kalati F, Bakhshani NM, Rasti M. Evaluation of the efficacy of low-level laser in improving the symptoms of burning mouth syndrome. I Clin Exp Dent. 2015 Oct 1;7(4):e524-7.

21. Arduino PG, Cafaro A, Garrone M, Gambino A, Cabras M, Rom agnoli $\mathrm{E}$, et al. A randomized pilot study to assess the safety and the value of low-level laser therapy versus clonazepam in patients with burning mouth syndrome. Lasers Med Sci. 2016 May;31(4):811-6.
22. Pezelj-Ribaric S, Kqiku L, Brumini G, Urek MM, Antonic R, Kuis D, et al. Proinflammatory cytokine levels in saliva in patients with burning mouth syndrome before and after treatment with lowlevel laser therapy. Lasers Med Sci. 2013 Jan;28(1):297-301.

23. Kato IT, Pellegrini VD, Prates RA, Ribeiro MS, Wetter NU, Sugaya NN. Low-level laser therapy in burning mouth syndrome patients: a pilot study. Photomed Laser Surg. 2010 Dec;28(6):835-9.

24. Romeo U, Del Vecchio A, Capocci M, Maggiore C, Ripari M. The low level laser therapy in the management of neurological burning mouth syndrome. A pilot study. Ann Stomatol (Roma). 2010 Jan;1(1):14-8. Epub 2010 Jun 29.

25. dos Santos Lde F, de Andrade SC, Nogueira GE, Leao JC, de Freitas PM. Phototherapy on the Treatment of Burning Mouth Syndrome: A Prospective Analysis of 20 Cases. Photochem Photobiol. 2015 Sep-Oct;91(5):1231-6.

26. dos Santos Lde F, Carvalho Ade A, Leao JC, Cruz Perez DE, Castro JF. Effect of lowlevel laser therapy in the treatment of burning mouth syndrome: a case series. Photomed Laser Surg. 2011 Dec;29(12):793-6.

27. Yang HW, Huang YF. Treatment of burning mouth syndrome with a low-level energy diode laser. Photomed Laser Surg. 2011 Feb;29(2):123-5.

28. Jo KB, Lee YJ, Lee IG, Park JY, Ahn R. Association of pain intensity, pain -related disability, and depression with hypothalamuspituitary-adrenal axis function in female patients with chronic temporomandibular disorders. Psychoneuroendocrinology. 2016 Jul;69:106-15.

29. Godfrey KM, Strachan E, Dansie E, et al. Salivary cortisol and cold pain sensitivity in female twins. Ann Behav Med. 2014 Apr;47(2):180-8.

30. Grotle M, Birger Hagen K. Placebo pills provided without deception may help to reduce pain and disability in people with chronic low back pain [synopsis]. J Physiother. 2017 Jul;63(3):183.

31. Oken BS. Placebo effects: clinical aspects and neurobiology. Brain. 2008 Nov;131(Pt 11):2812-23.

32. Colagiuri B, Schenk LA, Kessler MD, Dorsey SG, Colloca L. The placebo effect: from concepts to genes. Neuroscience. 2015 Oct 29;307:171-90.

33. Vukoja D, Alajbeg I, Vučićević Boras V, Brailo V, Alajbeg IZ, Andabak Rogulj $A$. Is effect of low-level laser therapy in patients with burning mouth syndrome result of a placebo? Photomed Laser Surg. 2011 Sep;29(9):647-8; discussion 648, 651.

34. Skrinjar I, Vidranski V, Loncar Brzak B, Vidovic Juras D, Andabak Rogulj A, Brailo V, et al. Salivary Cortisol Levels in Patients with Oral Lichen Planus - A Pilot Case-Control Study. Dent J (Basel). 2019 Jun 1;7(2). pii: E59. 